\title{
Деформація стінок лівого шлуночка при аневризмі та артеріальній гіпертензії
}

\author{
Мороз М. М., Лазоришинець В. В., Руденко А. В., Урсуленко В. І., \\ Трембовецька О. М., Ювчик О. В.
}

ДУ «Національний інститут серцево-судинної хірургії імені М. М. Амосова НАМН» (Київ)

\begin{abstract}
Артеріальна гіпертензія (АГ) є частим супутнім діагнозом у хворих із постінфарктною аневризмою лівого шлуночка (ЛШ). Мета роботи - дослідити вплив АГ на деформацію стінок ЛШ у хворих із постінфарктною аневризмою. Обстежено 63 пацієнти, що з діагнозом аневризма ЛШ знаходилися на лікуванні в «Національному інституті серцево-судинної хірургії імені М.М. Амосова НАМН» у період з 2012 по 2016 р. Досліджено параметри деформації стінок ЛШ у хворих з аневризмою залежно від наявності у них АГ. За допомогою векторної ЕхоКГ у хворих з аневризмою ЛШ і АГ виявлена тенденція до збільшення скручування і до зменшення показників подовжньої деформації.
\end{abstract}

Ключові слова: аневризма лівого шлуночка, артеріальна гіпертензія, деформація.

Аневризма серця являє собою обмежену ділянку стінки, що складається з некротичної або рубцевої тканини. У 85-90\% випадків аневризма локалізується у верхівкових, передньо-перегородкових сегментах ЛШ, будучи наслідком критичних стенозів і тромбозів передньої міжшлуночкової артерії [1-5].

За допомогою кількісної морфометрії було доведено, що ділянка, яка безпосередньо прилягає до зони ураження, розтягується, а в неушкодженій, далекій від інфаркту базальній зоні - кардіоміоцити, поряд із процесом сковзання, збільшуються як за довжиною, так і за об'ємом. Збільшені кардіомоцити мають певні особливості. В них менша чисельність бета- рецепторів і менша кількість повільних каналів відносно їх площі. Як наслідок - відбувається зменшення впливу на них нейрогуморальних компенсаторних механізмів симпатичної нервової системи і зниження сили скорочення [6].

Ультразвукова технологія «Speckle Tracking» дала можливість по-новому оцінити скоротливу здатність серця i, зокрема, іï найважливішу складову - подовжню деформацію міокарда. Виявилося, що при ураженні коронарних судин зменшується деформація поздовжніх волокон [7-9].

Згідно з даними останніх досліджень, у хворих з АГ відзначаються регіонарні порушення систолічної функції ЛШ. Маркером цих порушень теж є зміни подовжньої деформації. Радіальна деформація залишається збереженою. При вивченні показників циркулярної деформації у пацієнтів з АГ виявлено, що скручування ЛШ збільшується. Збільшення скручування відбувається за рахунок збільшення апікальної ротації. Радіальна і циркулярна систолічні функції тривалий час компенсують раннє порушення поздовжньої систолічної функції [10, 11].

Для значної частини пацієнтів з IXC і постінфарктною аневризмою ЛШ супутнім діагнозом є артеріальна гіпертензія.

Мета роботи - дослідити особливості деформації ЛШ при передньо-перегородковій аневризмі та АГ.

Матеріали та методи. Для діагностики аневризм, а також для оцінки функціонального стану міокарда використано метод комплексної эхокардіографії. Ехокардіографія була виконана на ультразвуковому апараті експертного класу VIVID E 9 фірми General Electric з використанням секторних датчиків зі змінною частотою від 1,5 до 5,0 Мгц.

За допомогою стандартної ЕхоКГ були визначені кінцевий систолічний і кінцевий діастолічний об'єми ЛШ і ФВ ЛШ (за Simpson), розраховані кінцево-діастолічний та кінцево-систолічний індекси об'єму та індекс ударного об'єму. В анатомічному В' режимі вимірювалася секторальна ФВ ЛШ (за Teicholtz).

За допомогою технологіï Speckle Tracking були визначені показники подовжньої деформації, скручування, ротації та зміщення [12, 13].

Після створення бази даних у программі Microsoft Excel проводилася статистична обробка результатів пакетом IBM SPSS Statistics 21.0.

Опис статистичних величин представлено залежно від їх типу та розподілу, що визначалося за параметричним критерієм Колмогорова- Смірнова. Для даних, розподіл яких відповідав нормальному, розраховано показники середніх величин і стандартне відхилення ( $\mathrm{M} \pm \mathrm{m}$, де $\mathrm{M}$ - середнє значення показника, $\mathrm{m}$ - стандартна погрішність середньої). При ненормальному 
розподілі розраховано медіани, квартилі, мінімальне та максимальне значення. При порівнянні величин користувалися коефіцієнтом Стьюдента для визначення їх достовірності. Різниця між показниками визнавалася достовірною при $\mathrm{p}<0,05$.

Об’єктом дослідження в даній роботі стали 63 пацієнти з передньо-перегородковою аневризмою ЛШ і нормокінезом неаневризматичної частини (середній вік 57,0 $\pm 9,4$ р., чоловіків - 84\%). Група була поділена на пацієнтів без гіпертонічної хвороби (I-A) і з гіпертонічною хворобою (І-Б). До контрольної групи ввійшли 35 здорових добровольців, які не висували скарги з боку серця та інших органів, а параметри їх стандартної ехокардіографіі знаходилися в межах норми (середній

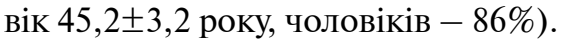

Результати та їх обговорення. У I-A групі були достовірно вищими за норму КДІ $(92,9 \pm 13,5)$ та

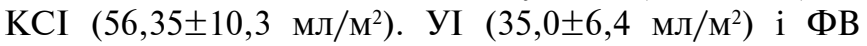
$(39,2 \pm 5,4 \%)$ були достовірно нижчими від норми. Секторальна ФВ на рівні неаневризматичної зони була вищою за 50\%. Систолічний артеріальний тиск становив $116,2 \pm 16,8$ мм рт. ст., діастолічний $-76,2 \pm 8,1$ мм рт. ст.

У І-Б групі були достовірно вищими за норму КДІ

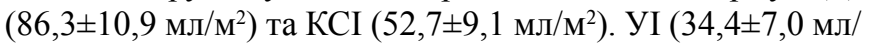
$\left.\mathrm{M}^{2}\right)$ і ФВ $(40,7 \pm 5,5 \%)$ були достовірно нижчими від норми $(\mathrm{p}=0,001)$. Секторальна ФВ на рівні базальних відділів перевищувала 50\%. Артеріальний тиск при проведенні дослідження був вищим, ніж у I-А групі і становив $136,6 \pm 15,9$ мм рт. ст., діастолічний $-83,2 \pm 8,6$ мм рт. ст. Показники стандартної ехокардіографії представлені в табл. 1.

Таким чином, незалежно від наявності АГ у хворих iз передньо-верхівково-перегородковою аневризмою спостерігалося збільшення показників КДІ, КСІ, ін-

\section{Таблиця 1}

Показники стандартної ехокардіографії пацієнтів із передньо-верхівково-перегородковою аневризмою ЛШ, нормокінезом неаневризматичної частини і артеріальною гіпертензією (група I-A - без артеріальної гіпертензії, група І-Б - з артеріальною гіпертензією)

\begin{tabular}{|c|c|c|c|c|}
\hline Параметр & $\begin{array}{l}\text { Норма } \\
(n=35)\end{array}$ & $\begin{array}{c}\text { Група I-A } \\
(n=31)\end{array}$ & $\begin{array}{c}\text { Група I -Б } \\
(n=32)\end{array}$ & $p$ \\
\hline КДІ, мл/М² & $65,7 \pm 9,0$ & $92,9 \pm 20,5^{*}$ & $86,3 \pm 14,9^{*}$ & 0,278 \\
\hline $\mathrm{KCl}, \mathrm{M} / \mathrm{M}^{2}$ & $23,8 \pm 4,9$ & $56,5 \pm 18,3^{*}$ & $52,7 \pm 12,1^{*}$ & 0,423 \\
\hline $\mathrm{VI}, \mathrm{мл} / \mathrm{M}^{2}$ & $44,5 \pm 8,3$ & $35 \pm 6,4^{*}$ & $34,4 \pm 7^{*}$ & 0,880 \\
\hline$\Phi B, \%$ & $65,5 \pm 5,3$ & $39,2 \pm 5,4^{*}$ & $40,7 \pm 5,5^{*}$ & 0,294 \\
\hline МШП, мм & $7,92 \pm 1,9$ & $11,2 \pm 1,5^{*}$ & $12,3 \pm 1,3^{*}$ & $0,001^{* *}$ \\
\hline Задн. ст., мм & $7,3 \pm 1,1$ & $9,1 \pm 2,6^{*}$ & $9,2 \pm 0,1,2^{*}$ & 0,825 \\
\hline ЛП, мм & $32,4 \pm 3,3$ & $4,31 \pm 0,37^{*}$ & $4,32 \pm 0,49^{*}$ & 0,902 \\
\hline $\begin{array}{l}\text { Індекс } \\
\text { сферичності }\end{array}$ & $0,28 \pm 0,17$ & $0,4 \pm 0,17^{*}$ & $0,37 \pm 0,17^{*}$ & 0,539 \\
\hline $\begin{array}{l}\text { Індекс } \\
\text { конусності }\end{array}$ & $0,6 \pm 0,1$ & $0,74 \pm 0,42^{*}$ & $0,94 \pm 0,17^{*}$ & 0,282 \\
\hline
\end{tabular}

*статистично достовірна різниця між показниками пацієнтів та норми на рівні $\mathrm{p}=0,05$

**статистично достовірна різниця між показниками пацієнтів групи I-A і групи І-Б на рівні $\mathrm{p}=0,05$

дексу сферичності, індексу конусності, а також зменшення УІ, ФВ. Ці ознаки не підсилювалися при наявності АГ. Однак при цьому за наявності АГ у хворих із нормокінезом неаневризматичної частини відмічалося збільшення товщини МШП. У пацієнтів з АГ товщина МШП (12,3 $\pm 1,3$ см) була достовірно більшою за тов-

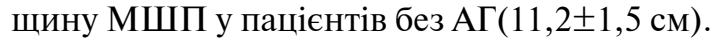

\section{Таблиця 2}

Середні значення деформації міокарда на базальному, середньому та верхівковому відділі ЛШ у нормі та у пацієнтів з передньо-верхівково-перегородковою аневризмою, нормокінезом неаневризматичної частини і АГ (група І-А - без АГ, група $l-5-3 A \Pi$

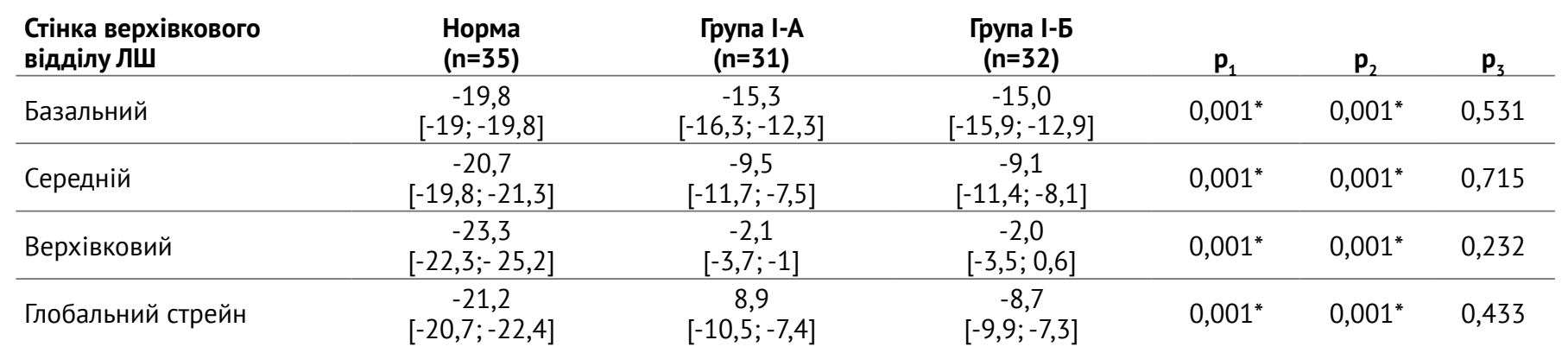

Примітка: * $\mathrm{p}_{1}-$ значущість відмінності між групою норми та групою I-А

$\mathrm{p}_{2}-$ значущість відмінності між групою норми та групою 1-Б

$\mathrm{p}_{3}$ - значущість відмінності між групою I-А та групою I-Б

*- різниця статистично значуща на рівні $\mathrm{p}=0,05$ 


\section{Таблиця 3}

Показники максимального скручування міокарда ЛШ в нормі і при передньо-верхівково-перегородковій аневризмі з нормокінезом неаневризматичної частини і АГ (група I-A - без гіпертонічної хвороби, група I-Б -з гіпертонічною хворобою)

\begin{tabular}{|c|c|c|c|c|c|c|}
\hline Параметр & $\begin{array}{l}\text { Норма } \\
(\mathrm{n}=35)\end{array}$ & $\begin{array}{c}\text { Група I-A } \\
(\mathrm{n}=31)\end{array}$ & $\begin{array}{c}\text { Група I-5 } \\
(n=32)\end{array}$ & $\mathbf{P}^{1}$ & $\mathbf{P}^{2}$ & $P^{3}$ \\
\hline Скручування & $\begin{array}{c}21 \\
{[19 ; 22]}\end{array}$ & $\begin{array}{c}9 \\
{[8 ; 12]}\end{array}$ & $\begin{array}{c}12 \\
{[8 ; 14]}\end{array}$ & $0,001^{*}$ & $0,001^{*}$ & 0,266 \\
\hline $\begin{array}{l}\text { Ротація } \\
\text { верхівкового відділу }\end{array}$ & $\begin{array}{c}14 \\
{[12 ; 14]}\end{array}$ & $\begin{array}{c}5 \\
{[4 ; 7]}\end{array}$ & $\begin{array}{c}6 \\
{[3 ; 8]}\end{array}$ & $0,001^{*}$ & $0,001^{*}$ & 0,565 \\
\hline $\begin{array}{l}\text { Ротація базального } \\
\text { відділу }\end{array}$ & $\begin{array}{c}-7 \\
{[-6 ;-8]}\end{array}$ & $\begin{array}{c}-4 \\
{[-6 ;-3]}\end{array}$ & $\begin{array}{c}-5 \\
{[-7 ;-3]}\end{array}$ & $0,001^{*}$ & $0,001^{*}$ & 0,213 \\
\hline
\end{tabular}

Примітка: * $\mathrm{p}_{1}$ - значущість відмінності між групою норми та групою I-A

$\mathrm{p}_{2}-$ значущість відмінності між групою норми та групою 1-Б

$\mathrm{p}_{3}-$ значущість відмінності між групою І-А та групою I-Б

*- різниця статистично значуща на рівні $\mathrm{p}=0,05$

Були визначені показники максимальної подовжньої деформації всіх сегментів ЛШ у трьох подовжніх апікальних зрізах у базальному, середньому і апікальному відділах у нормі та у пацієнтів із передньо-верхівково-перегородковою аневризмою, нормокінезом неаневризматичної частини з і без АГ. При порівняльному аналізі не було виявлено достовірної різниці між показниками сегментарної подовжньої деформації в цих групах. Та все ж, аналізуючи розраховані середні значення подовжньої деформації на базальному, середньому, верхівковому рівнях, можна дійти висновку, що існує тенденція до зменшення показників деформації у пацієнтів з АГ (табл. 2).
Значення максимального скручування міокарда ЛШ в нормі і у пацієнтів із передньо-верхівково-перегородковою аневризмою, нормокінезом неаневризматичної частини і АГ представлені в табл. 3.

Немає статистично значущої різниці між групами, та все ж відмічається тенденція до збільшення скручування у пацієнтів із передньо-верхівково-перегородковою аневризмою, нормокінезом неаневризматичної частини з АГ (група І-Б) відносно пацієнтів без АГ (група I-A).

Значення максимального подовжнього змішення всіх сегментів ЛШ у трьох подовжніх апікальних зрізах у базальному, середньому і апікальному відділах у нормі і у пацієнтів з передньо-верхівково-перегородковою

\section{Таблиця 4}

Показники максимального подовжнього зміщення сегментів базального відділу міокарда в нормі і у пацієнтів із передньо-верхівковою аневризмою, гіпокінезом неаневризматичної частини і АГ (група I-A - без АГ, група I-Б - з АГ)

\begin{tabular}{|c|c|c|c|c|c|c|}
\hline $\begin{array}{l}\text { Стінка базального } \\
\text { відділу ЛШ }\end{array}$ & $\begin{array}{l}\text { Норма } \\
(n=35)\end{array}$ & $\begin{array}{c}\text { Гpyna I-A } \\
(\mathrm{n}=31)\end{array}$ & $\begin{array}{c}\text { Група I-Б } \\
(n=32)\end{array}$ & $p_{1}$ & $p_{2}$ & $p_{3}$ \\
\hline $\begin{array}{l}\text { Нижньо- } \\
\text { перегородкова }\end{array}$ & $\begin{array}{c}17 \\
{[16 ; 19]}\end{array}$ & $\begin{array}{c}8 \\
{[7 ; 10]}\end{array}$ & $\begin{array}{c}8 \\
{[5 ; 10]}\end{array}$ & $0,001^{*}$ & $0,001^{*}$ & 0,876 \\
\hline Передньо- перегородкова & $\begin{array}{c}18 \\
{[16 ; 21]}\end{array}$ & $\begin{array}{c}6 \\
{[4 ; 7]}\end{array}$ & $\begin{array}{c}6 \\
{[3 ; 9]}\end{array}$ & $0,001^{*}$ & $0,001^{*}$ & 0,829 \\
\hline Передня & $\begin{array}{c}18 \\
{[16 ; 20]}\end{array}$ & $\begin{array}{c}7 \\
{[5 ; 9]}\end{array}$ & $\begin{array}{c}6 \\
{[4 ; 9]}\end{array}$ & $0,001^{*}$ & $0,001^{*}$ & 0,500 \\
\hline Бокова & $\begin{array}{c}19 \\
{[18 ; 21]}\end{array}$ & $\begin{array}{c}8 \\
{[6 ; 10]}\end{array}$ & $\begin{array}{c}6 \\
{[4 ; 9]}\end{array}$ & $0,001^{*}$ & $0,001^{*}$ & $0,038^{*}$ \\
\hline Задня & $\begin{array}{c}18 \\
{[17 ; 19]}\end{array}$ & $\begin{array}{c}9 \\
{[5 ; 12]}\end{array}$ & $\begin{array}{c}9 \\
{[5 ; 10]}\end{array}$ & $0,001^{*}$ & $0,001^{*}$ & 0,935 \\
\hline Нижня & $\begin{array}{c}20 \\
{[16 ; 21]}\end{array}$ & $\begin{array}{c}9 \\
{[7 ; 12]}\end{array}$ & $\begin{array}{c}9 \\
{[6 ; 12]}\end{array}$ & $0,001^{*}$ & $0,001^{*}$ & 0,557 \\
\hline
\end{tabular}

Примітка: * $\mathrm{p}_{1}$ - значущість відмінності між групою норми та групою I-A

$\mathrm{p}_{2}-$ значущість відмінності між групою норми та групою 1-Б

$\mathrm{p}_{3}$ - значущість відмінності між групою I-А та групою I-Б

* - різниця статистично значуща на рівні $\mathrm{p}=0,05$ 
аневризмою, нормокінезом неаневризматичної частини і АГ наведено в табл. 4.

На рівні базального сегмента бокової стінки відмічається статистично-достовірне зменшення зміщення у пацієнтів з АГ порівняно з пацієнтами без АГ, без статистично достовірної різниці по середньому значенню зміщення базального відділу ЛШ $(\mathrm{p}=0,185)$.

\section{Висновки}

1. Для всіх пацієнтів із передньо-верхівково-перегородковою аневризмою і нормокінезом неаневризматичної зони характерне збільшення КДІ та КСI, зменшення УІ та ФВ. Ці зміни не поглиблюються у хворих із АГ.

2. У пацієнтів з аневризмою ЛШ, нормокінезом неаневризматичної зони і АГ товщина МШП $(12,3 \pm 1,3$ см) достовірно більша за товщину МШП

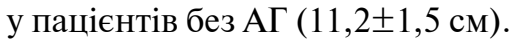

3. У пацієнтів з аневризмою ЛШ і АГ (порівняно 3 хворими з аневризмою ЛШ і без АГ) спостерігається достовірне зменшення зміщення базального сегмента бокової стінки і тенденція до зменшення показників деформації та збільшення показників скручування ЛШ.

\section{Література}

1. Доложенко М. Н. Аневризма левого желудочка: дефиниции, механизм формирования, диагностика, показания к операции и прогноз / Серцева недостатність. - 2009. - № 2. - С. 28-30.

2. Діагностика та лікування аневризм лівого шлуночка серця ішемічного генезу: автореф. дис. ... канд. мед. наук / Руденко С. А. - К., 2008. - С. 7.

3. Руденко А. В., Руденко С. А. Результати хірургічного лікування аневризм лівого шлуночка за методикою ендовентрикулопластики з латкою та без латки // Щорічник наукових праць Асоціації серцево-судинних хірургів Украіни. - 2009. - Вип. 17. - С. 558.

4. Результаты пластики левого желудочка после аневризмэктомии больших передневерхушечных, перегородочных и гигантских заднебазальных аневризм по данным повторной вентрикулографии / Урсуленко В. И., Руденко А. В., Якоб Л. В. и др. // Щорічник наукових праць Асоціації серцево-судинних хірургів Украіни. - 2009. - Вип. 17. C. 446.

5. Хирургия осложненных форм ишемической болезни сердца / Урсуленко В. И. - К. : Агат-Принт, 2016. C. $17-18$.

6. Физиология и патологическая физиология сердца / под ред. Н. Спереланис; пер.с англ. - М. : Медицина. - 1998. - Том № 2. - С. 192-195.

7. Поташов С. Диагностическая ценность современных методов визуализации сердца у пациентов с аневризмами левого желудочка // Серце і судини. - 2009. № 1. - С. 74-75.

8. Спекл-трекінг ехокардіографія: нормативні значення і роль методу у вивченні систолічної та діастолічної функції лівого шлуночка / Коваленко В. М., Несукай О. Г., Поленова Н. С. та ін. // Укр. кардіол. журн. 2012. - № 6. - C. 103-109.

9. Left ventricular global longitudinal strain is associated with exercise capacity in failing hearts with preserved and reduced ejection fraction / Hasselberg N. E., Hauga K. H., Sarvari S. I. et al. // Eur Heart J Cardiovasc Imaging. 2015. - Vol. 16. - P. 217-224.

10. Дзяк Г. В. Новые возможности в оценке структурно-функционального состояния миокарда при гипертонической болезни / Г. В. Дзяк, М. Ю. Колесник // Здоров'я України. - 2013. - Тем. номер. C. $24-25$.

11. Speckle-tracking and tissue-Doppler echocardiography in arterial hypertension: a sensitive tool for detection of subclinical LV impairment / Hensel K. O., Jenke A., Leischik R. // J. Biomed. Res. Int. - 2014. - Vol. 4. P. 725-62.

12. Definitions for a common standard for $2 \mathrm{D}$ speckle tracking echocardiography: consensus document of the EACVI/ ASE/Industry Task Force to standardize deformation imaging / Voigt J. U., Pedrizzetti G., Lysyansky P. et al. // Eur Heart J Cardiovasc Imaging. - 2015. - Vol. 16. P. $1-11$.

13. Assessment of left ventricular systolic function by deformation imaging derived from speckle tracking: a comparison between $2 \mathrm{D}$ and $3 \mathrm{D}$ echo modalities/ Altman M., Bergerot C., Davidsen E. S. et al. // Eur Heart J Cardiovasc Imaging. - 2014. - Vol. 15. - P. 316-323.

\title{
THe deformation of left ventricular walls in aneurism and arterial hypertension
}

\author{
Moroz M. M., Lazoryshinetz V. V., RudenkoA. V., Ursulenko V. I., Trembovetskaya O. M., Juvchik O. V. \\ National M. M. Amosov Institute of Cardiovascular Surgery \\ National Academy of Medical Sciences of Ukraine (Kyiv)
}

Arterial hypertension ( $\mathrm{AH})$ is a frequent concomitant diagnosis in patients with postinfarction left ventricular (LV) aneurysm.

Objective: to investigate the effect of hypertension on the deformation of the walls of LV in patients with postinfarction aneurysm.

Patients (63) of the «National Institute of Cardio -Vascular Surgery» in the period from 2012 - 2016 with a diagnosis of aneurysm LV were investigated. The parameters of the deformation of the stems LV have been determined. Due to 
vectoring echocardiography the tendencies of enlargement curvature of LV the tendencies of the decline of the longitudinel deformation were detected.

Key words: aneurism of left ventricular, arterial hypertension, deformation.

\section{Деформация стенок левого желудочка при аневризме и артериальной гипертензии}

Мороз М. Н., Лазоришинец В. В., Руденко А. В., Урсуленко В. И., Трембовецкая Е. М., Ювчик Е. В.

ГУ «Национальный институт сердечно-сосудистой хирургии имени Н. М. Амосова НАМН» (Киев)

Артериальная гипертензия (АГ) является частым сопутствующим диагнозом у больных с постинфарктной аневризмой левого желудочка (ЛЖ).

Цель работы - исследовать влияние АГ на деформацию стенок ЛЖ у больных с постинфарктной аневризмой.

Обследовано 63 пациента с диагнозом аневризма ЛЖ, которые находились на лечении в «Национальном институте сердечно-сосудистой хирургии имени Н. М. Амосова НАМН» в период с 2012 по 2016 г. Исследованы параметры деформации стенок ЛЖ у больных с аневризмой в зависимости от наличия у них АГ. С помощью векторной ЭхоКГ у больных с аневризмой ЛЖ и АГ выявлена тенденция к увеличению скручивания и тенденция к снижению показателей продольной деформации.

Ключевые слова: аневризма левого желудочка, артериальная гипертензия, деформация. 